International Journal of Current Advanced Research

ISSN: O: 2319-6475, ISSN: P: 2319 - 6505, Impact Factor: SJIF: 5.995

Available Online at www.journalijcar.org

Volume 6; Issue 3; March 2017; Page No. 2515-2519

DOI: http://dx.doi.org/10.24327/ijcar.2017.2519.0040

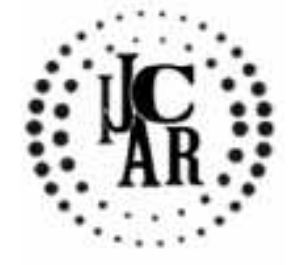

Research Article

\title{
PHYSIOCHEMICAL PROPERTIES OF OILJFWPB, RECOVERED BY THE OXIDATIVE THERMAL DEGRADATION OF THE MIXTURE OF HDPE, LDPE AND JUTE FIBER
}

\section{Vijesh Verma., Savita Dixit* and Gajendra Dixit}

Department of Chemistry Maulana Azad National Institute of Technology, Bhopal India 462051

\begin{tabular}{|c|c|}
\hline A R T I C L E I N F O & A B S T R A C T \\
\hline Article History: & The Oil JFWPB was recovered by the oxidative thermal degradation of the mixture of HDPE, \\
\hline $\begin{array}{l}\text { Received } 11^{\text {th }} \text { December, } 2016 \\
\text { Received in revised form } 19^{\text {th }} \text { January, } 2017 \\
\text { Accepted } 8^{\text {th }} \text { February, } 2017 \\
\text { Published online } 28^{\text {th }} \text { March, } 2017\end{array}$ & $\begin{array}{l}\text { LDPE and Jute fiber. According to the GC/MS analysis, it was reported that chemically } \\
\text { Oil } \text { JFWPB }_{\text {consisted of a phytol, two saturated fatty acids, two unsaturated fatty acids and two }} \\
\text { silica containing derivatives. Five blends of Oil } \mathrm{l}_{\mathrm{JPWPB}} \text { were prepared with Diesel (Reference } \\
\text { fuel) and the basic physiochemical fuel properties such as Density, Viscosity, Kinematic } \\
\text { Viscosity, Flash Point, Fire Point, Cloud Point, Pour Point and Calorific Value were } \\
\text { determined by using ASTM methods. }\end{array}$ \\
\hline
\end{tabular}

Key words:

Oxidative thermal degradation, hdpe, ldpe,

jute fiber, Oil ${ }_{\mathrm{JFWPB}}$, physiochemical properties

Copyright $@ 2017$ Savita Dixit et al. This is an open access article distributed under the Creative Commons Attribution License, which permits unrestricted use, distribution, and reproduction in any medium, provided the original work is properly cited.

\section{INTRODUCTION}

Waste to energy (WTE) technology is a promising way to transform the municipal solid waste (MSW) into the energy resource. According to Plastic Europe Market Research Group, the reported global production of plastic is 322 million tons (PEMRG) in which only United States individually contributes 250 million tons of municipal solid waste (MSW) (Staley, 2009) which generates numerous environmental problems. Pyrolysis is a thermal degradation process of organic materials which operated at very high temperature in oxygen less environment. On pyrolysis of plastic by mixing biomass causes the improvement in liquid product yield than the plastics pyrolyzed individually (Brebu, 2010). Copyrolysis of plastic waste with different biomass such as karanja \& niger seeds (Shadangi, 2015), red oak (Xue, 2015), rice husk (Costa, 2014), almond shell (Önal, 2013), oil shell (Aboulkas, 2012), pine cone (Brebu, 2010), wood biomass (Sharypov, 2002), forestry biomass wastes (Paradela, 2009), lignocellulosic materials (Jakab, 2001) has been studied widely. Oxidative thermal degradation of the waste High Density Polyethylene (HDPE) and Low Density Polyethylene (LDPE) by mixing Jute fiber is a novel pathway to obtained high yield of liquid fuel from polyethylene waste (Dixit, 2016).

\section{*Corresponding author: Savita Dixit}

Department of Chemistry Maulana Azad National Institute of Technology, Bhopal India 462051

\section{MATERIAL AND METHOD}

The Oil JFWPB was recovered by the oxidative thermal degradation of the mixture of HDPE, LDPE and Jute fiber (Dixit, 2016). The five blends of Oil $\mathrm{JFWPB}_{\mathrm{JF}}$ i.e. $\mathrm{Oil}_{\mathrm{JFWPB}}-10 \%$, $\mathrm{Oil}_{\mathrm{JFWPB}}-20 \%, \mathrm{Oil}_{\mathrm{JFWPB}}-30 \%, \mathrm{Oil}_{\mathrm{JFWPB}}-40 \%$ and $\mathrm{Oil}_{\mathrm{JFWPB}}-50 \%$ were prepared with the Diesel (Reference fuel) for the determination of basic physiochemical fuel properties.

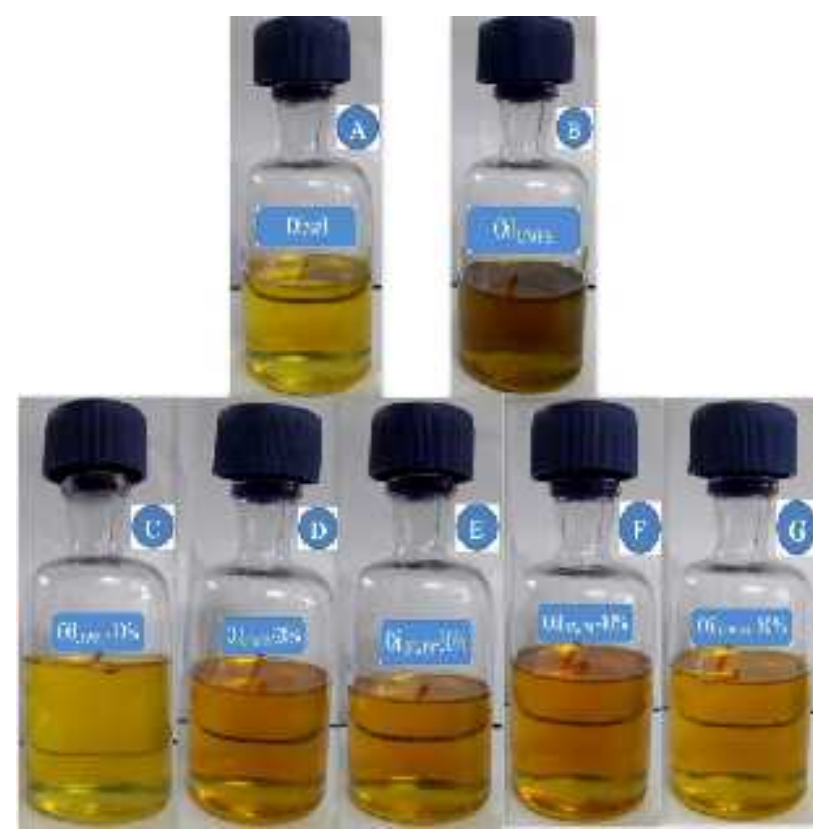

Figure 1 A: Diesel, B: Oil $1_{\mathrm{JFWPB}}, \mathrm{C}-\mathrm{G}$ : prepared five blends, respectively 
In this research work the five blends of Oil $1_{\mathrm{JFWPB}}$ were prepared with Diesel (Reference fuel) and by following the ASTM methods the basic physiochemical properties of the blends were determined and compared with Diesel.

\section{Preparation and nomenclature of the blends of Oil ${ }_{J F W P B}$ with Diesel}

For the preparation of each blend, the appropriate fractions of Oil $_{\text {JFWPB }}$ and Diesel were taken in a 1 Liter beaker by using measuring cylinder and then with the help of magnetic stirrer the mixture of Oil $_{\text {JFWPB }}$ and Diesel were stir for 30 minutes, to make the uniform mixture of fuel. The actual picture of the Oil $_{\text {JFWPB }}$ and their five blends with Diesel shown in Figure 1. Nomenclature and composition of the blends of Oil $1_{\mathrm{JFWPB}}$ with Diesel were summarized in Table 1.

Table 1 Nomenclature and composition of the blends of Oil $_{\text {JFWPB }}$

\begin{tabular}{cccc}
\hline S.N. & Name of the blend & $\begin{array}{c}\text { Fraction of } \\
\text { Oil }_{\mathrm{JFWPB}}(\mathbf{m l})\end{array}$ & $\begin{array}{c}\text { Fraction of } \\
\text { Diesel (ml) }\end{array}$ \\
\hline 1. & Diesel (Reference fuel) & 00 & 1000 \\
2. & Oil $_{\mathrm{JFWPB}}-10 \%$ & 100 & 900 \\
3. & Oil $_{\mathrm{JFWPB}}-20 \%$ & 200 & 800 \\
4. & Oill $_{\mathrm{JFWPB}}-30 \%$ & 300 & 700 \\
5. & Oil $_{\mathrm{JFWPB}}-40 \%$ & 400 & 600 \\
6. & Oil $_{\mathrm{JFWPB}}-50 \%$ & 500 & 500 \\
\hline
\end{tabular}

\section{Standard methods}

The ASTM methods and apparatus which were used to determine the fuel properties summarized in Table 2.
Table 2 Standard apparatus and methods for the fuel properties

\begin{tabular}{|c|c|c|c|}
\hline S.N. & Fuel properties & Standards apparatus & ASTM methods \\
\hline 1. & Density $\left(\mathrm{g} / \mathrm{cm}^{3}\right)$ & $\begin{array}{c}\text { Gay-Lussac specific gravity } \\
\text { bottle }\end{array}$ & $\begin{array}{c}\text { ISI } \\
\text { 1448[P:32]:1992 }\end{array}$ \\
\hline 2. & $\begin{array}{l}\text { Viscosity }(\mathrm{m} \mathrm{Pa} \mathrm{S}) \\
\text { Kinematic }\end{array}$ & A N D Viscometer SV 10 & Digital Viscometer \\
\hline 3. & $\begin{array}{l}\text { Viscosity } \\
\text { (c St) }\end{array}$ & Redwood Viscometer No. 1 & ASTM D 445 \\
\hline 4. & Flash Point $\left({ }^{\circ} \mathrm{C}\right)$ & Abel's closed cup apparatus & ASTM D 93 \\
\hline 5. & Fire Point $\left({ }^{\circ} \mathrm{C}\right)$ & Abel's closed cup apparatus & ASTM D 93 \\
\hline 6. & Cloud Point $\left({ }^{\circ} \mathrm{C}\right)$ & $\begin{array}{c}\text { Cloud Point determination } \\
\text { apparatus }\end{array}$ & ASTM D 2500 \\
\hline 7. & Pour Point $\left({ }^{\circ} \mathrm{C}\right)$ & $\begin{array}{c}\text { Pour Point determination } \\
\text { apparatus }\end{array}$ & ASTM D 97 \\
\hline 8. & $\begin{array}{c}\text { Calorific Value } \\
(\mathrm{MJ} / \mathrm{Kg})\end{array}$ & Digital Bomb Calorimeter & IS:1448[P:6]:1984 \\
\hline
\end{tabular}

\section{RESULTS AND DISCUSSION}

\section{Chemical composition of the $\mathrm{Oil}_{J F W P B}$}

According to the GC/MS analysis of $\mathrm{Oil}_{\mathrm{JFWPB}}$, in the Total ion chromatogram (Figure 2) the 14 major peaks were recorded in which seven chemical compounds (Table 3) were, a phytol identified as 3,7,11,15- Tetramethyl -2-hexadecen-1-ol (Figure 2 (B)), two saturated fatty acids, Methyl tetradecanoate and Pentadecanoic acid, 14-methyl- methyl ester (Figure 2(C) \& 2(E)), two unsaturated fatty acids, 7Hexadecenoic acid, methyl ester, (Z) (Figure 2 (D)) and 9Octadecenoic acid (Z)-, methyl ester (Figure $2(\mathrm{~F})$ ) and 2

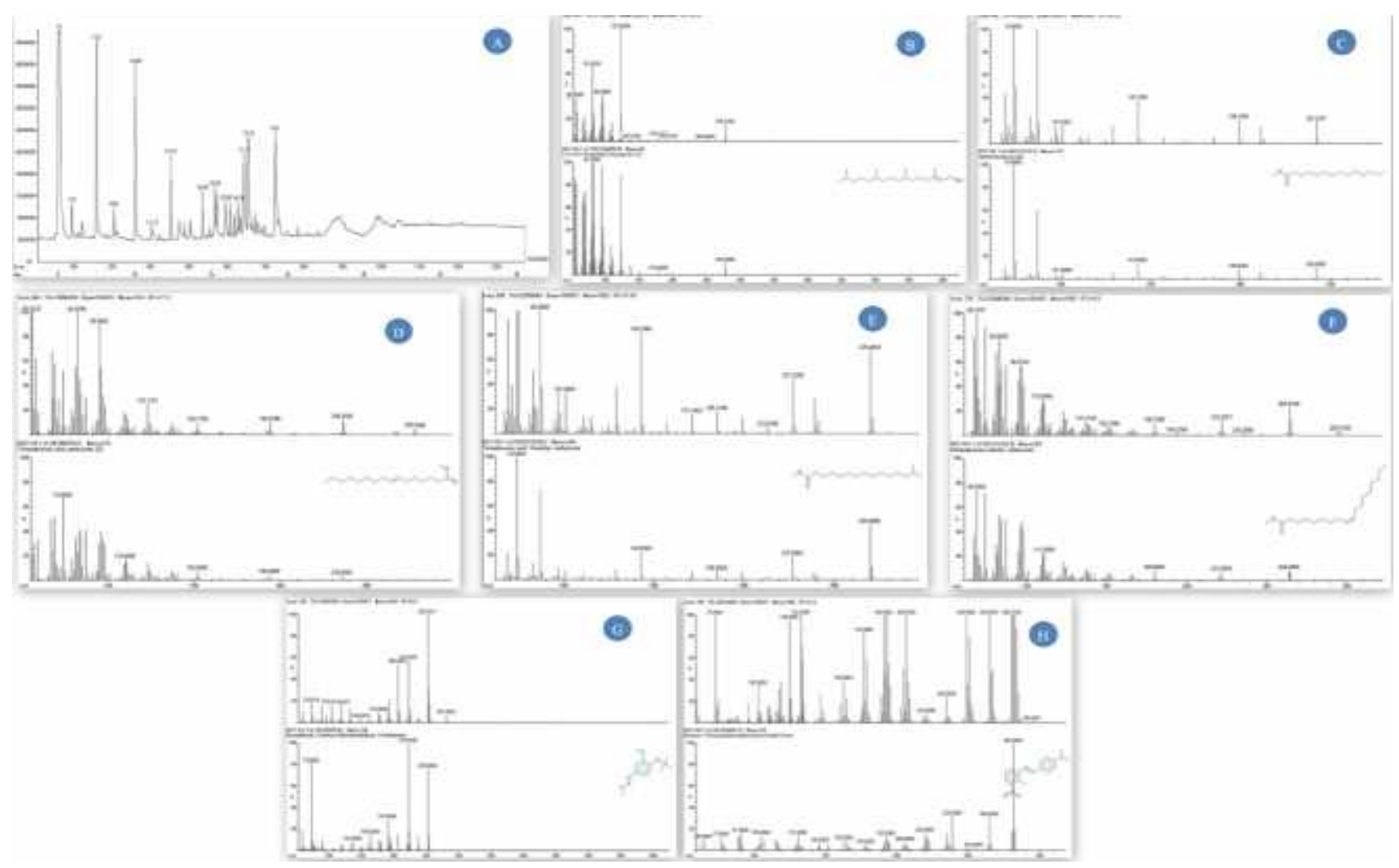

Figure 2 GC/MS analysis of $\mathrm{Oil}_{\mathrm{JFWPB}}$ 

hdpe, ldpe and jute fiber

Table 3 The GC/MS analysis of Oil $\mathrm{JFWPB}_{\mathrm{J}}$

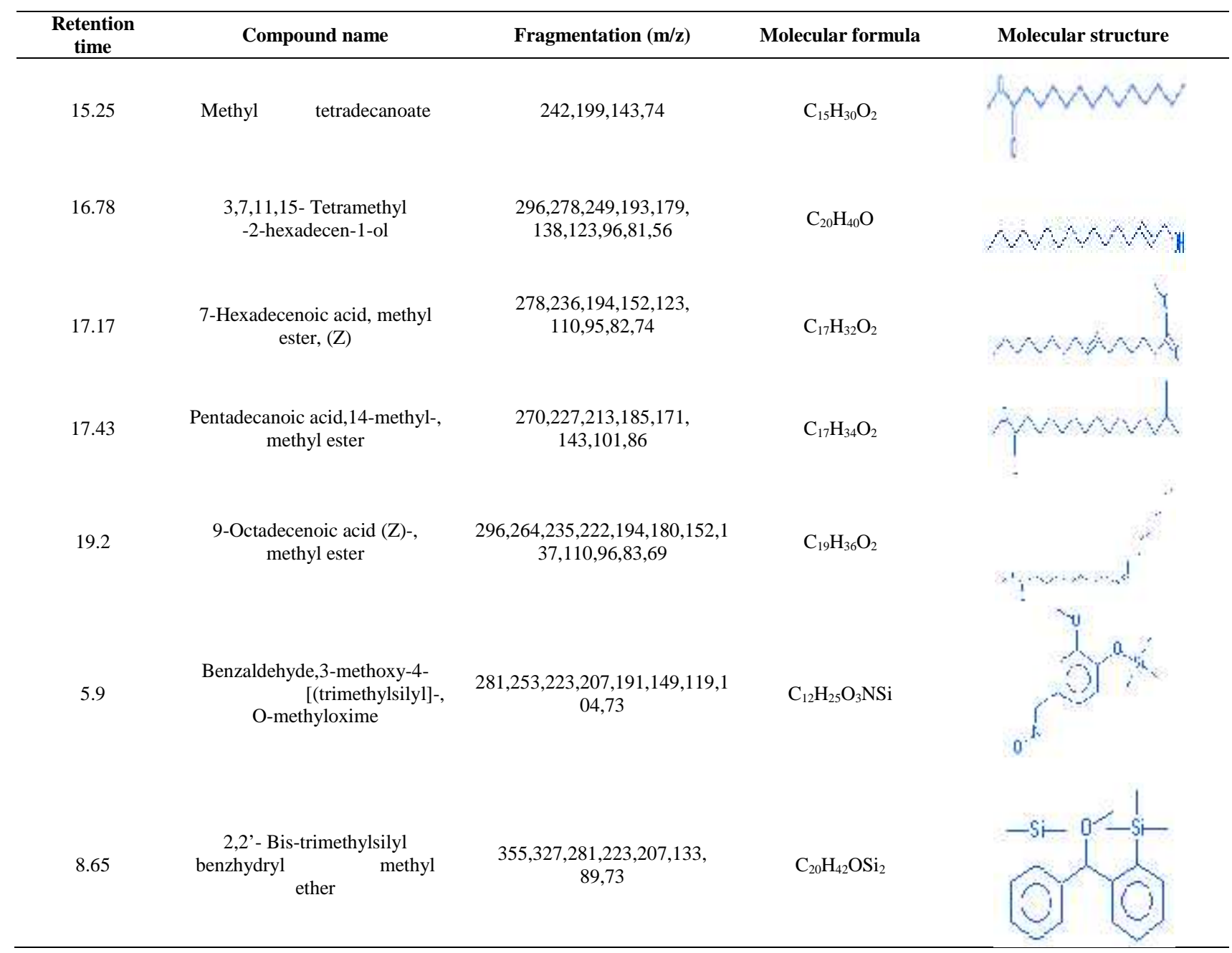

silica containing derivatives (Figure $2(\mathrm{G}) \& 2(\mathrm{H})$ ). On the basis of the molecular structure the tentative average chemical formula of the Oil $\mathrm{JFWPB}_{\mathrm{JFP}}$ can be calculated and obtained as $\mathrm{C}_{17.14} \mathrm{H}_{34.14} 0_{1.85} \mathrm{~N}$ (Silica not included) whiles the average chemical formula of Diesel is $\mathrm{C}_{12} \mathrm{H}_{23}$ ).

\section{Physiochemical properties of Oil $_{J F W P B}$}

\section{Density}

The variation in Density of $\mathrm{Oil}_{\mathrm{JFWPB}}-10 \%$, $\mathrm{Oil}_{\mathrm{JFWPB}}-20 \%$, $\mathrm{Oil}_{\mathrm{JFWPB}}-30 \%, \mathrm{Oil}_{\mathrm{JFWPB}}-40 \%$, $\mathrm{Oil}_{\mathrm{JFWPB}}-50 \%$ and Diesel shown in Figure 3 (A), were $0.7751 \mathrm{~g} / \mathrm{ml}, 0.7734 \mathrm{~g} / \mathrm{ml}, 0.7717 \mathrm{~g} / \mathrm{ml}$, $0.7700 \mathrm{~g} / \mathrm{ml}, 0.7683 \mathrm{~g} / \mathrm{ml}$ and 0.7768 respectively. The Density of $\mathrm{Oil}_{\mathrm{JFWPB}}-10 \%$, $\mathrm{Oil}_{\mathrm{JFWPB}}-20 \%$, $\mathrm{Oil}_{\mathrm{JFWPB}}-30 \%$, $\mathrm{Oil}_{\mathrm{JFWPB}}-40 \%, \mathrm{Oil}_{\mathrm{JFWPB}}-50 \%$ is decreased by $0.21 \%, 0.43 \%$, $0.65 \%, 0.87 \%, 1.09 \%$ as compared to Diesel respectively. According to the physical properties of the blends, it was clear that Density decreases with increase of the fraction of Oil $_{\text {JFWPB }}$ in each blend. Decrease in Density indicates that every blend getting lighter than Diesel respectively.

\section{Viscosity}

The variation in Viscosity of $\mathrm{Oil}_{\mathrm{JFWPB}}-10 \%$, Oil ${ }_{\mathrm{JFWPB}}-20 \%$, $\mathrm{Oil}_{\mathrm{JFWPB}}-30 \%, \mathrm{Oil}_{\mathrm{JFWPB}}-40 \%$, Oil $\mathrm{JFWPB}_{\mathrm{JW}}-50 \%$ and Diesel shown in Figure 3 (B), were 3.6, 3.45, 3.34, 3.2, 3.05 and 3.66 respectively.
The Viscosity of $\mathrm{Oil}_{\mathrm{JFWPB}}-10 \%$, $\mathrm{Oil}_{\mathrm{JFWPB}}-20 \%$, $\mathrm{Oil}_{\mathrm{JFWPB}}-30 \%$, $\mathrm{Oil}_{\mathrm{JFWPB}}-40 \%$, Oil $\mathrm{JFWPB}-50 \%$ are decreased by $1.63 \%, 5.73 \%$, $8.74 \%, 12.56 \%, 16.66 \%$ as compared to Diesel. Decrease Viscosity indicates that every blend getting thinner than Diesel respectively.

\section{Kinematic Viscosity}

The variation in Kinematic Viscosity of $\mathrm{Oil}_{\mathrm{JFWPB}}-10 \%$, $\mathrm{Oil}_{\mathrm{JFWPB}}-20 \%, \mathrm{Oil}_{\mathrm{JFWPB}}-30 \%, \mathrm{Oil}_{\mathrm{JFWPB}}-40 \%, \mathrm{Oil}_{\mathrm{JFWPB}}-50 \%$ and Diesel shown in Figure 3 (C), were 10.07, 9.09, 7.73, $5.93,3.99$ and 10.41 respectively. The Kinematic Viscosity of Oil $_{\mathrm{JFWPB}}-10 \%$, Oil ${ }_{\mathrm{JFWPB}}-20 \%$, Oil JFWPB $-30 \%$, Oil $\mathrm{JFWPB}-40 \%$, $\mathrm{Oil}_{\mathrm{JFWPB}}-50 \%$ were decreased by $3.26 \%, 12.68 \%, 25.74 \%$, $43.03 \%, 61.67 \%$ as compared to Diesel.

\section{Flash Point}

The variation in Flash Point of $\mathrm{Oil}_{\mathrm{JFWPB}}-10 \%$, Oil $\mathrm{JFWPB}_{\mathrm{JFW}}-20 \%$, $\mathrm{Oil}_{\mathrm{JFWPB}}-30 \%, \mathrm{Oil}_{\mathrm{JFWPB}}-40 \%$, Oil $\mathrm{JFWPB}-50 \%$ and Diesel shown in Figure 3 (D), were $48{ }^{\circ} \mathrm{C}, 42{ }^{\circ} \mathrm{C}, 32{ }^{\circ} \mathrm{C}, 30{ }^{\circ} \mathrm{C}, 29{ }^{\circ} \mathrm{C}$ and $58{ }^{\circ} \mathrm{C}$ respectively. The Flash Point of $\mathrm{Oil}_{\mathrm{JFWPB}}-10 \%$, Oil $_{\text {JFWPB }}-20 \%$, Oil JFWPB $-30 \%$, Oil JFWPB $-40 \%$, Oil JFWPB $-50 \%$ are decreased by $17.2 \%, 27.5 \%, 44.8 \%, 48.2 \%, 50 \%$ as compared to Diesel respectively. 


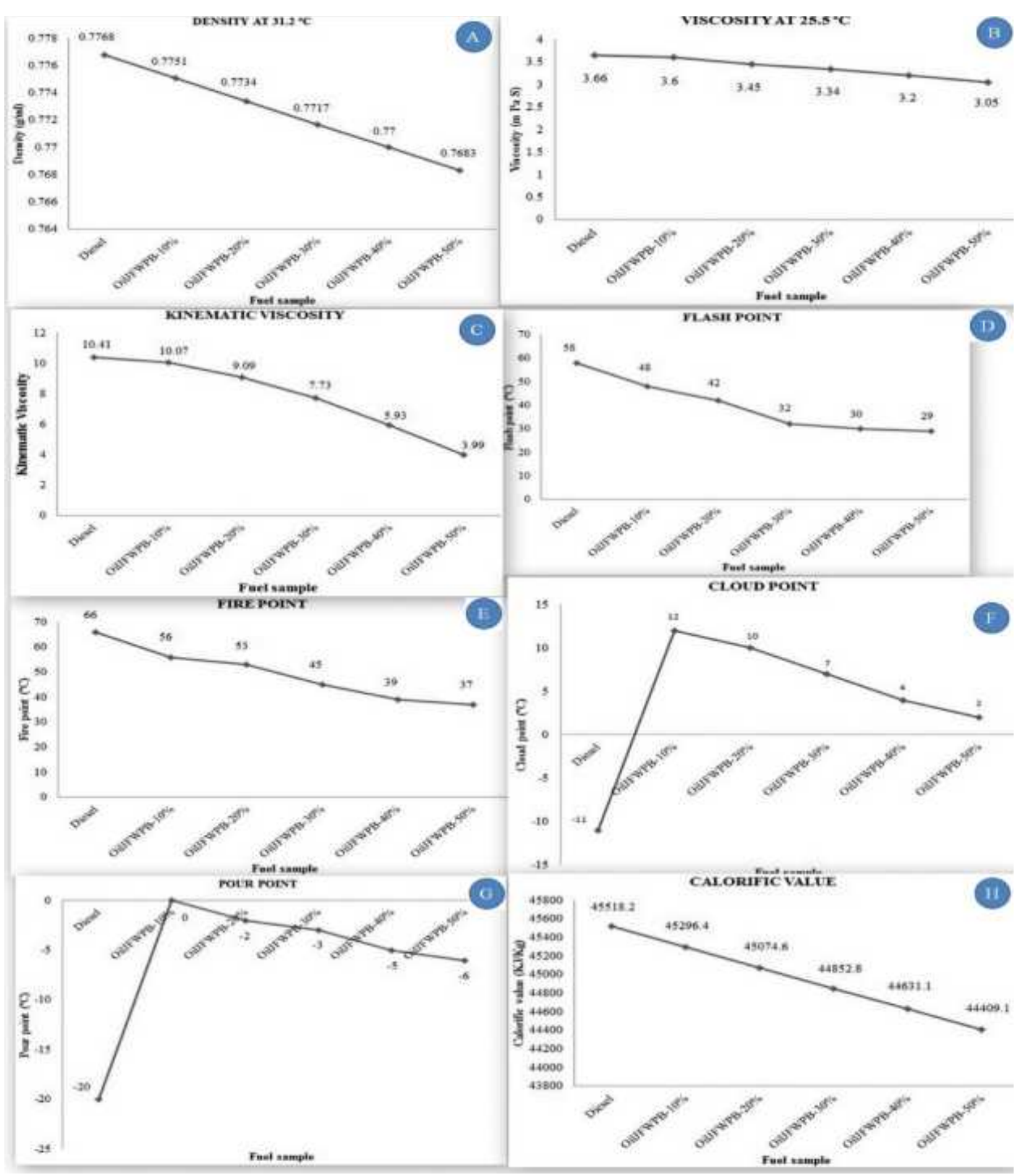

Figure 3 Physiochemical properties of Oil $\mathrm{JFWPB}_{\mathrm{F}}$, A: Density, B: Viscosity, C: Kinematic Viscosity, D: Flash Point, E: Fire Point, F: Cloud Point, G: Pour Point, H: Calorific Value respectively.

Table 4 Physiochemical fuel properties of all the five blends of Oil $1_{\text {JFWPB }}$ with respect to Diesel

\begin{tabular}{|c|c|c|c|c|c|c|c|c|c|}
\hline S.N. & Name of the blend & $\begin{array}{c}\text { Density at } \\
31.2^{\circ} \mathrm{C} \\
(\mathrm{g} / \mathrm{ml})\end{array}$ & $\begin{array}{l}\text { Viscosity } \\
\text { at } 25.5^{\circ} \mathrm{C} \\
(\mathrm{m} \mathrm{Pa} \mathrm{S})\end{array}$ & $\begin{array}{c}\text { Kinematic } \\
\text { Viscosity }\end{array}$ & $\begin{array}{c}\text { Flash } \\
\text { Point } \\
\left({ }^{\circ} \mathrm{C}\right) \\
\end{array}$ & $\begin{array}{l}\text { Fire } \\
\text { Point } \\
\left({ }^{\circ} \mathrm{C}\right) \\
\end{array}$ & $\begin{array}{c}\text { Cloud } \\
\text { Point } \\
\left({ }^{\circ} \mathrm{C}\right) \\
\end{array}$ & $\begin{array}{l}\text { Pour } \\
\text { Point } \\
\left({ }^{\circ} \mathrm{C}\right) \\
\end{array}$ & $\begin{array}{c}\text { Calorific } \\
\text { Value } \\
\text { (KJ/Kg) }\end{array}$ \\
\hline 1. & Diesel & 0.7768 & 3.66 & 10.41 & 58 & 66 & -11 & -20 & 45518.2 \\
\hline 2. & Oil $_{\mathrm{JFWPB}}-10 \%$ & 0.7751 & 3.60 & 10.07 & 48 & 56 & 12 & 0 & 45296.4 \\
\hline 3. & Oil $_{\text {JFWPB }}-20 \%$ & 0.7734 & 3.45 & 9.09 & 42 & 53 & 10 & -2 & 45074.6 \\
\hline 4. & Oil $_{\mathrm{JFWPB}}-30 \%$ & 0.7717 & 3.34 & 7.73 & 32 & 45 & 7 & -3 & 44852.8 \\
\hline 5. & Oil $_{\text {JFWPB }}-40 \%$ & 0.7700 & 3.20 & 5.93 & 30 & 39 & 4 & -5 & 44631.1 \\
\hline 6. & Oil $_{\text {JFWPB }}-50 \%$ & 0.7683 & 3.05 & 3.99 & 29 & 37 & 2 & -6 & 44409.1 \\
\hline
\end{tabular}


The variation in Fire Point of Oil $_{\mathrm{JFWPB}}-10 \%$, Oil $\mathrm{JFWPB}_{\mathrm{JF}}-20 \%$, $\mathrm{Oil}_{\mathrm{JFWPB}}-30 \%$, $\mathrm{Oil}_{\mathrm{JFWPB}}-40 \%$, Oil $\mathrm{JFWPB}_{\mathrm{J}}-50 \%$ and Diesel shown in Figure $3(\mathrm{E})$, were $56{ }^{\circ} \mathrm{C}, 53{ }^{\circ} \mathrm{C}, 45{ }^{\circ} \mathrm{C}, 39{ }^{\circ} \mathrm{C}, 37{ }^{\circ} \mathrm{C}$ and $6^{\circ} \mathrm{C}$. The Fire Point of Oil ${ }_{\mathrm{JFWPB}}-10 \%$, Oil $\mathrm{JFWPB}-20 \%, \mathrm{Oil}_{\mathrm{JFWPB}^{-}}$ $30 \%$, Oil ${ }_{\mathrm{JFWPB}}-40 \%$, Oil $_{\mathrm{JFWPB}}-50 \%$ are decreased by $15.1 \%$, $19.6 \%, 31.8 \%, 40.9 \%, 43.9 \%$ as compared to Diesel respectively. It was clear that flash and Fire Point decreases with increase of the fraction of Oil $_{\mathrm{JFWPB}}$ in each blend. Decrease in Density and Viscosity indicates that every blend getting lighter and thinner than Diesel respectively, hence the Flash and Fire Point of each blend also decreases.

\section{Cloud Point}

The variation in Cloud Point of $\mathrm{Oil}_{\mathrm{JFWPB}}-10 \%$, $\mathrm{Oil}_{\mathrm{JFWPB}}-20 \%$, $\mathrm{Oil}_{\mathrm{JFWPB}}-30 \%, \mathrm{Oil}_{\mathrm{JFWPB}}-40 \%, \mathrm{Oil}_{\mathrm{JFWPB}}-50 \%$ and Diesel shown in Figure $3(\mathrm{~F})$, were $12{ }^{\circ} \mathrm{C}, 10{ }^{\circ} \mathrm{C}, 7{ }^{\circ} \mathrm{C}, 4{ }^{\circ} \mathrm{C}, 2{ }^{\circ} \mathrm{C}$ and -11 ${ }^{\circ} \mathrm{C}$ respectively.

\section{Pour Point}

The variation in Pour Point of $\mathrm{Oil}_{\mathrm{JFWPB}}-10 \%$, Oil $\mathrm{JFWPB}_{\mathrm{JP}}-20 \%$, Oil $_{\mathrm{JFWPB}}-30 \%$, $\mathrm{Oil}_{\mathrm{JFWPB}}-40 \%$, $\mathrm{Oil}_{\mathrm{JFWPB}}-50 \%$ and Diesel shown in Figure $3(\mathrm{G})$, were $0{ }^{\circ} \mathrm{C},-2{ }^{\circ} \mathrm{C},-3{ }^{\circ} \mathrm{C},-5{ }^{\circ} \mathrm{C},-6{ }^{\circ} \mathrm{C}$ and -20 ${ }^{\circ} \mathrm{C}$ respectively.

\section{Calorific Value}

The variation in Calorific Value of $\mathrm{Oil}_{\mathrm{JFWPB}}-10 \%$, $\mathrm{Oil}_{\mathrm{JFWPB}^{-}}$ $20 \%, \mathrm{Oil}_{\mathrm{JFWPB}}-30 \%, \mathrm{Oil}_{\mathrm{JFWPB}}-40 \%$, Oil $\mathrm{JFWPB}_{\mathrm{JF}}-50 \%$ and Diesel shown in Figure $3(\mathrm{H})$, were $45296.4 \mathrm{KJ} / \mathrm{Kg}, 45074.6 \mathrm{KJ} / \mathrm{Kg}$, $44852.8 \mathrm{KJ} / \mathrm{Kg}, 44631.1 \mathrm{KJ} / \mathrm{Kg}, 44409.1 \mathrm{KJ} / \mathrm{Kg}$ and 45518.2 $\mathrm{KJ} / \mathrm{Kg}$ respectively. The Calorific Value of $\mathrm{Oil}_{\mathrm{JFWPB}}-10 \%$, $\mathrm{Oil}_{\mathrm{JFWPB}}-20 \%$, $\mathrm{Oil}_{\mathrm{JFWPB}}-30 \%, \mathrm{Oil}_{\mathrm{JFWPB}}-40 \%$, $\mathrm{Oil}_{\mathrm{JFWPB}}-50 \%$ are decreased by $0.48 \%, 0.97 \%, 1.46 \%, 1.94 \%, 2.43 \%$ as compared to Diesel respectively.

The characteristic basic physiochemical fuel properties of all the five blends of $\mathrm{Oil}_{\mathrm{JFWPB}}$ i.e. $\mathrm{Oil}_{\mathrm{JFWPB}}-10 \%$, Oil $\mathrm{JFWPB}_{\mathrm{JFW}}-20 \%$, $\mathrm{Oil}_{\mathrm{JFWPB}}-30 \%, \mathrm{Oil}_{\mathrm{JFWPB}}-40 \%$ and $\mathrm{Oil}_{\mathrm{JFWPB}}-50 \%$ with respect to Diesel summarized in Table 4.

\section{CONCLUSION}

It was concluded that, for all the five blends i.e. $\mathrm{Oil}_{\mathrm{JFWPB}}-10 \%$, $\mathrm{Oil}_{\mathrm{JFWPB}}-20 \%, \mathrm{Oil}_{\mathrm{JFWPB}}-30 \%, \mathrm{Oil}_{\mathrm{JFWPB}}-40 \%$ and $\mathrm{Oil}_{\mathrm{JFWPB}^{-}}$ $50 \%$;

1. The Density decreased by $0.21 \%, 0.43 \%, 0.65 \%$, $0.87 \%$ and $1.09 \%$ as compared to Diesel.

2. The Viscosity decreased by $1.63 \%, 5.73 \%, 8.74 \%$, $12.56 \%$ and $16.66 \%$ as compared to Diesel.

3. The Kinematic Viscosity decreased by $3.26 \%$, $12.68 \%, 25.74 \%, 43.03 \%$ and $61.67 \%$ as compared to Diesel.

4. The Flash Point decreased by $17.2 \%, 27.5 \%, 44.8 \%$, $48.2 \%$ and $50 \%$ as compared to Diesel.
5. The Fire Point decreased by $15.1 \%, 19.6 \%, 31.8 \%$, $40.9 \%$ and $43.9 \%$ as compared to Diesel.

6. The variation in Cloud Point was $12{ }^{\circ} \mathrm{C}, 10{ }^{\circ} \mathrm{C}, 7{ }^{\circ} \mathrm{C}$, $4{ }^{\circ} \mathrm{C}$ and $2{ }^{\circ} \mathrm{C}$ as compared to Diesel.

7. The variation in Pour Point was $0{ }^{\circ} \mathrm{C},-2{ }^{\circ} \mathrm{C},-3{ }^{\circ} \mathrm{C},-5$ ${ }^{\circ} \mathrm{C}$ and $-6{ }^{\circ} \mathrm{C}$ as compared to Diesel.

8. The Calorific Value decreased by $0.48 \%, 0.97 \%$, $1.46 \%, 1.94 \%$ and $2.43 \%$ as compared to Diesel respectively.

\section{References}

1. PlasticsEurope (PEMRG) / Consultic

2. Staley, B.F. Barlaz, M.A. 2009. Composition of municipal solid waste in the United States and implications for carbon sequestration and methane yield. J Environ Eng., 135: 901-9.

3. Shadangi, K.P. Mohanty, K. 2015. Co-pyrolysis of Karanja and Niger seeds with waste polystyrene to produce liquid fuel. Fuel., 153: 492-498.

4. Xue, Y. Zhou, S. Brown, R.C. Kelkar, A. Bai, X. 2015. Fast pyrolysis of biomass and waste plastic in a fluidized bed reactor. Fuel., 156: 40-46.

5. Costa, P. Pinto, F. Miranda, M. André, R. Rodrigues, M. 2014. Study of the experimental conditions of the co-pyrolysis of rice husk and plastic wastes. Chem Eng., 39: 1639-1644.

6. Önal, E. Uzun, B.B. Pütün, A.E. 2013. Bio-oil production via co-pyrolysis of almond shell as biomass and high density polyethylene. Energy Convers Manage., 78: 704-10.

7. Aboulkas, A. Makayssi, T. Bilali, L. harfi, K.,El. Nadifiyine, M. Benchanaa, M. 2012. Co-pyrolysis of oil shale and High density polyethylene: Structural characterization of the oil. Fuel Processing Technology., 96: 203-208.

8. Brebu, M. Ucar, S. Vasile, C. Yanik, J. 2010. Copyrolysis of pine cone with synthetic polymers. Fuel., 89: 1911-8.

9. Sharypov, V.I. Marin, N. Beregovtsova, N.G. Baryshnikov, S.V. Kuznetsov, B.N. Cebolla, V.L. 2002. Co-pyrolysis of wood biomass and synthetic polymer mixtures. Part I: influence of experimental conditions on the evolution of solids, liquids and gases. J Anal Appl Pyrol., 64: 15-28.

10. Paradela,F. Pinto, F. Ramos, A.M. Gulyurtlu, I. Cabrita, I. 2009. Study of the slow batch pyrolysis of mixtures of plastics, tyres and forestry biomass wastes. J Anal Appl Pyrol., 85: 392-8.

11. Jakab, E. Blazsó, M. Faix, O. 2001. Thermal decomposition of mixtures of vinyl polymers and lignocellulosic materials. J Anal Appl Pyrol., 58: 4962.

12. Dixit, S. Dixit, G. Verma, V. 2016. Thermal degradation of polyethylene waste and jute fiber in oxidative environment and recovery of oil containing phytol and free fatty acids. Fuel, 179: 368-375.

\section{How to cite this article:}

Vijesh Verma et al(2017) ' Physiochemical properties of oiljfwpb, recovered by the oxidative thermal degradation of the mixture of hdpe, ldpe and jute fiber', International Journal of Current Advanced Research, 06(03), pp. 2515-2519. DOI: http://dx.doi.org/10.24327/ijcar.2017.2519.0040 